https://doi.org/10.18485/bogoljub_stankovic.2018.ch20

811.163.41'367.626

РАДОСЛАВА ТРНАВАЦ

Универзитет у Новом Саду

Филозофски факултет

\title{
СИСТЕМ НЕГАТИВНЕ ЕВАЛУАЦИЈЕ У РУСКОМ JЕЗИКУ
}

Рад се бави описивањем прелиминарне таксономије лингвистичких средстава која се користе ради исказивања негативне евалуације у руском језику. Дескрипција таксономије се базира на асистираном корпусном методу.

Кљуине речи: негативна евалуација, таксономија, системско-функционална лингвистика, лексикограматика, дискурсивна семантика

Radoslava Trnavac

\section{THE SYSTEM OF THE NEGATIVE EVALUATION IN THE RUSSIAN LANGUAGE}

This paper describes a preliminary taxonomy of linguistic resources which are used for expression of negative evaluation in the Russian language. The presented taxonomy is based on a corpus-assisted method of the analysis.

Key words: negative evaluation, taxonomy, Systemic functional linguistics, lexicogrammar, discourse semantics

Циљ датог рада је да се опише прелиминарна таксономија лингвистичких средстава за изражавање негативне евалуације у руском језику. За постизање постављеног циља користили смо анализу онлајн текстова са руске верзије гугла, као и интуитивни метод говорника руског језика.

Евалуативни аспект језика изражава осећања, оцене људи, ситуација и објеката, као и супротстављање мишљења различитих говорника. Повећано интересовање за субјективност, евалуацију и изражавање мишљења се може тумачити као својеврсни „афективни обрт” у фило-

*rtrnavac@ff.uns.ac.rs 
зофији, социологији и политичким наукама (Clough and Halley 2007), што је блиско правцу афективне калкулације у области вештачке интелигенције (Picard 1997). Дато интересовање је интензивирано појавом друштвених мрежа, као и могућношћу да се јавно, путем мрежа, преносе емоције, оцене и мишљења.

Студије евалуације, афекта и субјективности представљају мултидисциплинарни пројекат који укључује социологију (Voas 2014), психологију (Ortony et al. 1988), економију (Rick and Loewenstein 2008) и информатику (Pang and Lee 2008; Scherer et al. 2010; Cambria and Hussain 2012; Liu 2010, 2012). У лингвистици различити правци се баве евалуацијом, као што су теорија оцене (Martin and White 2005), става (Biber and Finegan 1989), евалуације (Вольф 2009; Hunston and Thompson 2000) и неверидикалности (Taboada and Trnavac 2013). У оквиру информатике савремена истраживања се фокусирају на аутоматску екстракцију мишљења у оквиру три нивоа (Liu 2012) - документа, реченице и домена. Први ниво класификује целокупна документа као позитивне или негативне. Други се бави субјективном оријентацијом и поларитетом мишљења (позитивног или негативног), који су представљени редоследом речи субјективног карактера у реченици. Трећи ниво се заснива на екстракцији мишљења базираног на одређеним текстуалним доменима или жанровима. Методе за екстракцију које се употребљавају у сваком од наведена три нивоа се заснивају на различитим приступима, укључујући употребу репрезентација базираних на субјективним и граматичким везама. Овакве врсте модела се баве комплексним језиком који укључује негацију, спекулацију, као и различите феномене условљене контекстом.

Постоји велики број прегледа евалуативне литературе у области рачунарске и примењене лингвистике. Ханстон и Томсон (2000) демонстрираују у својој књизи Евалуација у йексйу како евалуативни изрази могу бити анализирани на лексичком, граматичком и текстуалном нивоу. Недавна студија Томсонове и Албе Јуазове (Thompson, AlbaJuez 2014) се фокусира на теоретске и емпиријске студије евалуативног текста у оквиру фонолошког, лескичког и семантичког нивоа, као и на различите текстуалне жанрове и контексте. Рачунарски приступи евалуативном тексту, који се сврставају у ред сентимент анализе, највише су обрађени у студијама Панга и Лија (Pang and Lee 2008) и Лија (Liu 2010, 2012).

Наш фокус у овом раду би било прелиминарно постављање модела за лингвистичко изражавање негативне евалуације или мишљења. Обимна анализа евалуативног језика би требало да води изучавању експресије негативности и негативне евалуације из неколико разлога. Први разлог би била хипотеза да људска врста има склоности ка нега- 
тивном. Наиме, ми снажније перцепирамо негативне догађаје и емоције. Претходно истраживање указује на то да језици имају тенденцију да поседују више позитивних него негативних речи и да су негација и негативност асиметрични у односу на своје позитивне еквиваленте. у даљем тексту ћемо појаснити изложене тврдње.

Аутори у оквиру психолошке литературе тврде да људи имају склоности ка негативним догађајима и емоцијама јер их доживљавају као снажније односу на позитивне догађаje (Jing-Schmidt 2007; Rozin et al. 2010; Rozin \& Royzman 2001). Розин и Ројзман (2001) описују негативне догађаје и емоције као оне које имају „заразни” ефекат. Склоност ка негативном има неколико аспеката од којих су фундаментална два - негативна потенција и негативна доминантност. Негативна потенција указује на снагу негативних догађаја и искустава: „ако узмемо позитивне и негативне догађаје исте јачине, негативни догађај је субјективно моћнији и изражајнији него његов позитивни еквивалент (Rozin \& Royzman 2001: 298). У бихевијоралним наукама и економији то се описује као феномен аверзије према губитку. Губитак се посматра као упечатљивији од добитка. На пример, губитак $100 \$$ је болнији догађај него радост због добитка од 100\$ (Kahneman \& Tversky 1979). Негативна доминантност обухвата чињеницу да „холистичка перцепција и оцена интегрисаних негативних и позитивних догађаја [...] је негативнија него алгебарска сума субјективних вредности тих индивидуалних догађаја". Ова тенденција људске врсте према негативном се понекада објашњава и у смислу еволуције: делотворније је за људе да обраћају пажњу на претње и негативне догађаје (нпр. предаторе) него да обраћају пажњу на позитивне догађаје. Слични аргументи се употребљавају при објашњавању порекла емоције гађења, која се описује као механизам за избегавање потенцијалних смртоносних патогених организама, што се касније проширило и на морално гађење (Curtis 2013). Литерарни теоретичар и реторичар Кенет Бурке има поставку да је негирање фундаментално људско обележје, део нашег симболичког система и део нашег језика. „У време када нам је сугерисано, чак и у песмама, да се фокусирамо на йозийивно и када неки експерти зарађују велики новац пишући инспиративне радове у којима хвале моћ позитивног размишљања, друга клауза моје дефиниције људске врсте мора узети на себе незахвални задатак прослављања тог посебног људског бисера - негативног." (Burke 1966: 9). 


\section{1. Већа фреквентност позитивног језика}

Језици имају више позитивних него негативних речи и обично се позитивне речи користе фреквентније. Боучер и Осгуд (1969) су прикупили материјал из 13 језика и култура, и пронашли су да се позитивне речи користе фреквентније у поменутим језицима. То је довело до тога да се предложи тз. хипотеза полијане, која највероватније представља универзалну тенденцију. Гарсија и др. (2012) су пронашли потврду дате хипотезе анализирајући речи које изражавају емоције у три различита језика - речи са позитивним емотивним садржајем су пронађене чешће у гугловој Н-грам бази. У онлајн рецензијама текстова који су детаљно проучавани у оквиру области сентимент анализе (Pang \& Lee 2008) налазимо више позитивних него негативних рецензија, и више позитивних него негативних речи у оквиру самих рецензија. Такође, хедонометарски пројекат (Dodds et al. 2015) је показао већу фреквентност позитивних речи на твитеру. Из разлога што има више позитивних примера у доступним базама метод сентимент анализе има тенденцију да врши ефикаснију анализу позитивних реченица него негативних или неутралних реченица (Ribeiro et al. 2016). Ова већа фреквентност позитивног језика изгледа да је контрадикторна у односу на постојање склоности ка негативном. Па ипак, ова два стања се могу помирити ако их посматрамо као комплементарне. Ми анализирамо позитивне догађаје и емоције чешће јер су негативни догађаји и емоције непријатни и имају „заразни” ефекат. Јингшмит (2007: 424) то дефинише на следећи начин „Ми говоримо о светлијој страни живота, али то није исто што и посматрати свет из оптимистичније перспективе".

\section{2. Асиметрична природа негације и негативности у језику}

У неколико аспеката у језику позитивно и негативно су асиметрични и неједнаки (Horn 1989; Israel 2004). Као што је већ поменуто у претходном одељку, позитивне речи су фреквентније него негативне речи. На морфолошком нивоу, негативне речи у руском језику су често изведене од корена позитивне речи са додатком извесног афикса (красивый - некрасивыц ), мада постоје изузеци од тог правила (на пример, незаірязненный). Негирана позитивна реч је негативна (несчастный). Негирана негативна реч је често неутрална - негрустныци, на пример, је неутрална реч. Приликом грађења комбинација која се састоје од два прилога, често се позитиван прилог јавља први у многим језицима (Rozin et al. 2010). 
Негација има снажан ефекат на прагматском нивоу. Негација позитивне речи није њен прецизан обрнути еквивалент. На пример, ако је реч хороший благо позитивна, нехороший не би била благо негативна, већ много снажније негативна. Дакле, треба се запитати због чега је негативност негативна, али не представља прецизан обрнути еквивалент од позитивног.

У овом раду бисмо поставили модел лингвистичих средстава који у руском изражавају негативност. С обзиром да су негативни изрази мање фреквентни и више маркирани, они се избегавају када преносе негативност, те се други лингвистички изрази активирају осим негативних речи. Циљ у овом раду јесте да се предложи таксономија лингвистичких алатки које руски језик користи да би пренео негативност са специјалним фокусом на лексикограматичке изразе и на дискурсивну семантику.

\section{3. Прелиминарна таксономија - лингвистичке алатке негативне евалуације}

Изражавање евалуације у општим оквирима се постиже уз помоћу више језичких нивоа. Теорија оцене је показала да се евалуација и мишљење могу пренети захваљујући лексичком, граматичком и дискурсивном материјалу (Martin 2014; Martin \& White 2005). Приликом скицирања прелиминарне таксономије дошли смо до закључка да постоје средства која се употребљавају за постизање жељеног ефекта, што подразумева укључивање реторичких фигура као централних алатки у евалуативном језику. Сматрамо да су реторичке фигуре посебно значајне у изражавању негативне евалуације која представља фокус овог рада. У овом одељку ћемо описати средства за која сматрамо да су фундаментална за дату таскономију.

Једна таква таксономија у којој би биле описане фразе, изрази и лингвистичке алатке за изражавање негативности може да има различите почетне инстанце. Формална таксономија може бити креирана на основу категоризације различитих врста речи, синтаксичких структуpa, конструкција (Goldberg 2006) и образаца (Hunston 2011; Hunston \& Francis 2000). Таксономија би такође могла бити структуирана на основу семантичког приступа класификацији различитих типова негативности, као што је то урађено у оквиру теорије оцене (Martin \& White 2005). Сматрамо да би за почетак било добро кренути од динамичке таксономије. Она садржи различите лингвистиче алатке, али ставља акценат на средства која су употребљена ради постизања ефекта на слушаоца односно читаоца. Дакле, предлажемо неку врсту прагматичке таксономије. Такође, лингвистичке алатке које су класификоване у оквиру ове 
таксономије могу бити подељене у две велике групе - оне које припадају плану лексикограматике и плану дискурсивне семантике. Поменута два плана представљају део системске функционалне лингвистике (Halliday 1985; Halliday \& Matthiessen 2014).

\section{Фигура 1: Таксономија средстава за креирање негативне евалуације}

Лексикограматика укључује сва граматичка средства у језику (начин, транзитивност, информациону структуру) заједно са лексиком. Дискурсивна семантика (понекад једноставно семантика) у оквиру системске функционалне лингвистике се бави значењима која су креирана кроз текст и која су обухваћена системима транзитивности, начина и теме, и испитивањем кохезије и кохерентности текстова (Martin 1992). Ми сматрамо да у оквиру категорије дискурсивне семантике постоји посебно место за истраживање реторичког аспекта који језик користи. Највећи број дескриптивних радова који су писани у оквиру системске функционалне граматике не третира ове експресивне аспекте језика, остављајући то за теорију оцене (Martin \& White 2005). Лексикограматика се може дефинисати као скуп лексичких, фразеолошких и граматичких средстава у језику. Други план експресије укључује дискурсивну семантику, али такође и употребу лексикограматичких средстава у циљу постизања ефекта. Дихотомија се фундаментално ствара између статичке и реторичке структуре. Као и са свим осталим класификацијама, чиста сепарација између две категорије није могућа; дискурсивна семантика и реторичке фигуре нису обавезно забележени у лексикограматици. Ово нису групе које се међусобно искључују, већ категорије које укључују једна другу. Морамо истаћи да системско-функционална граматика упражњава још један додатни план или компоненту у језику осим лексикограматике, а то су фонологија и графологија. Фонолошки ниво није укључен у дату таксономију јер ми првенствено радимо са текстом, али понеке фонолошке алатке као што су рима и алитерације јесу укључене у реторички ниво. Графолошки аспекти, посебно емотикони, сва велика слова, као и неколико узвичника, такође доприносе исказивању негативности, али то је простор у који ми не бисмо залазили у оквиру датог рада. Студије језика из реторичке перспективе обухватају два велика аспеката - структуру аргумената и студије фигура и тропа. Студије аргумената указују на организацију делова дискурса, логичке конекције између делова текста и начин на који се граде аргументи. Једна од теорија која се бави проучавањема аргумената је реторичка структурална теорија (Mann \& Thompson 1988). Као што само њено име указује, она се бави реторичким ефектима, пре свега првим типом - како су 
аргументи изграђени од компонентих делова са интенцијом креирања ефекта на читаоца или слушаоца. Реторичка структурална теорија се бави питањем комбинације пропозиција у дискурсу и ослања се на кохерентност кроз пропозиционе односе. Она је сигурно део таксономије, на реторичком нивоу или на нивоу дискурсивне семантике. У овом раду, ипак, нама је релевантнији други тип реторичких алатки, употреба лингвистичких средстава у виду фигура и тропа. Реторичке фигуре представљају креативну организацију речи да би се постигао одређени ефекат. Тропи такође представљају креативну употребу значења речи, али уз праћење стила (Keith \& Lundberg 2008). Примери таквих средстава су хиперболе и сарказам.

Поменута дескрипција горњих нивоа наше таксономије укључује средства подељена на феномене у оквиру лексикограматике и на феномене у оквиру дискурсивне семантике.

\section{4. Феномени у оквиру лексикограматике}

\section{1 Морфологија}

Морфологија може бити укључена у исказивање негативности. На пример, многи суфикси имају у исто време деминутивно и дерогативно значење - городишко, лгунишка, штанишки, аgвокатишка, мужичонка, избенка, работешка, итд.

\section{2 Лексика}

Индивидуалне речи имају јасно евалуативни карактер и многе могу бити веома лако класификоване као позитивне или негативне. Креиране листе позитивних и негативних речи данас се у рачунарској лингвистици користе за сентимент анализу и детекцију емоција. Додатно, постоје речи које не садрже сопствени поларитет, али се ипак чешће налазе у оквиру негативног контекста. На пример, израз как gоказательство се обично виђа у негативном окружењу. На сличан начин и неки прилози, као што је то прилог на самом gеле, рефлектују негативну оцену.

\section{3 Личне заменице}

Основна разлика између првог и другог, са једне стране, и трећег лица, са друге стране, је релевантна у изражавању негативне евалуације. У ситуацијама директног напада користи се друго лице, а понекада и вокатив. 
- Да тьм маньяк!

- О Миша, грязная яуша в тисках расчётливого мира!

Треће лице такође може да се користи у циљу критиковања или у дерогативном смислу.

(3) В меморандуме Бэняа выясняется как раз то, о чем gавно говорили критики клинтонов - они почти не разграничивают иастную и общественную сферы своей жизни, не провояят четких различий межуу стремлением к личному обогащению, управлением некоммерческой организаиией и участием в политической жизни США (Иносми.ru, 28.10. 2016).

\section{4 Темпорални адвербијали}

Неки темпоријални адвербијали се користе у негативном контексту ради изражавања нестрпљења.

- наконещ, он сказал правgу.

\section{5 Семантичка или дискурсивна прозодија}

Семантичка прозодија указује на интринзички позитивну или негативну конотацију коју носи реч захваљујући својој асоцијацији са експлицитно позитивним или негативним објектима или ситуацијама

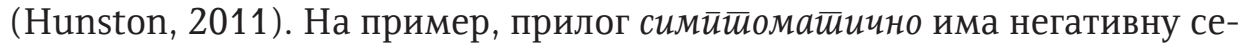
мантичку прозодију, што је илустровано у следећем примеру:

- Отсутствие женщин в этих комитетах оченв симптоматично, так как они являются именно теми структурами, которые gолжны внедрять в наииональное законодательство межяународные гендерные приоритеты и правовые нормы (сајт Reverso Context).

\section{6 Фразеологија}

Одређене комбинације речи, фраза и израза имају тенденцију да се користе чешће у контекстима са негативном евалуацијом, као на пример изрази разве не?, нет сомнения, проблема в том, ито..., труяно поверить, ито... Такође, у оквиру ове групације налазе се идиоми који су фиксирани у својој структури и значењу.

- Ояно из gвух: плати - не то играй слугу; Попробуй отказать, так он согнет в gугу (Молотков 1986: 109). 


\section{5. Феномени у оквиру дискурсивне семантике}

Феномени и средства који су описани у претходном одељку припадају слоју лексикограматике, дакле нивоу језика у оквиру реченице. У овом делу рада говорићемо о средствима која су укључена у оквире дискурсивних и прагматичких односа, дакле оних који се налазе изнад реченичног нивоа или оних који могу бити интерпретирани само на основу контекста. Ово укључује реторичка средства која се ослањају на ефекте креиране за слушаоце/читаоце и самим тим контекст је од прворазредног значаја.

\section{1 Директан и индиретан говор}

Цитирање дела текста који се анализира или нечијег експлицитног или имплицитног размишљања доприноси негативном ефекту. Посебно у онлајн коментарима, коментатори цитирају делове чланка или друге коментаре да би истакли оно што они сматрају да је погрешно речено. Графички, постоји преклапање у коришћењу цитирања као механизма за дистанцирање, што је слично изразу „такозвни”, као у споју „либеральные элиты „. Као пример цитирања у вези са негативним ефектом може се навести следећи текст:

(7) И в этих условиях, когgа мы не уванаем лияеров запаgных стран, сиитая, что они марионетки и не облаяают межяунарояной правовой субъектностью, мы как бы игнорируем экономически. В экономическом плане Запаяная Европа - это главный наш партнер и экономический и торговый. И мы как бы говорим: «Ну вот то, что у нас такая часть ВВП опосpеgуется обменом в Запаgной Европе, тий финㅗ. Вот в политике мы противостоим». Ну, как монно игнорировать тот факт, ито экономическое благополучие так наглухо завязано на Запаяную Европу, что монно легкомысленно говорить: «Мы переориентируемся на Восток». Это непослеgовательность (Независимая газета, 7.05. 2018).

Аутор изјава, Констатин Ремчуков, изражава негативну оцену према ниподаштавајућем ставу о сарадњи са Западном Европом цитирајући дати став.

\section{2 Реторичка питања}

Реторичка питања снажно потврђују или негирају одређену тачку гледишта, те укључују јаку емотивну димензију. У негативном контексту она обично започињу лексикализованом реченичном основом: 
- Почему ты такой злой?

- Разве невозможно покониить с этим раз и навсегgа?

5.3 Реторичке фигуре

Под реторичким фигурама се посматра креативна употреба језика ради неког ефекта, било да је то комбинација речи (фигуре) или манипулација значењима (тропе). Овде ћемо навести неколико реторичких фигура које играју важну улогу у грађењу негативне евалуације. То су хипербола, антитеза, метафоре, литоте, иронија, понављања. Навешћемо примере за сваку од поменутих фигура:

Мейафора
(10) Жизнь - это gожgь... Сплошной gожgь... Иногgа он моросит мелкими капельками, иногgа перехоgит в ливень.

Приликом исказивања исте, ради добијања негативне оцене, најчешће се нека појава или личност упоређују са негативним извором.

\section{Хииеррбола}

- Мы не вияелись стполет!

Употребом хиперболе врши се реторичко преувеличавање које се постиже кроз поређења и метафоре. У претходном примеру акценат се ставља на дужину времена које је прошло откада су се актери последњи пут видели.

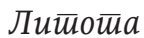

- Жизнь человека-о оин миг.

Литота је стилска фигура која је супротна хиперболи јер умањује одређени израз замењујући га слабијим који обично носи негативну оцену.

\section{Иронија и сарказам}

- Гgе уж нам, gуракам, иай пить!

Сарказам и иронија су тропе које подразумевају промене у значењу чијом употребом се проширује или алудира на значење које треба поново да буде интерпретирано у новом контексту. Обично постоји дискотинуитет између онога шта је речено и начина на који се нешто интерпретира. Сарказам укључује четири различите компоненте (Goddard 
2016): (а) контра-очекивање, (б) преувеличавање, (в) интенцију да се буде занимљив и (г) агресивност. Дефиниције сарказма и ироније су веома блиске, са незнатним разликама. Иронија имплицира супротно ономе што неко каже, често постоји доза ругања или шале, док дефиниција сарказма обухвата „ругање, вербални подсмех или горку иронију”. Ми их у овом раду групишемо у оквиру исте категорије.

\section{Анйитеиеза}

(14) Россия-страна рабов, страна госпоg.

Међу стилским фигурама често се јавља антитеза, контрастирајуће речи или идеје, које су обично смештене у оквиру паралелних структура.

\section{Оксиморон}

\section{(15) Взрослье gети!}

Оксиморон подразумева две супротне идеје које су присаједињене заједно да би се створио одређени стилски ефекат. Често дати ефекат носи негативну евалуацију.

\section{6. Закључак}

Циљ овог рада је био да се проучи лингвистички израз негативне евалуације, као и да се опише прелиминарна типологија изражавања негативне оцене у руском језику. Наш претходни рад на евалуативном језику нас је водио ка изучавању изражавања негативности и негативне евалуације, уз хипотезу по којој људска врста има склоности да снажније перцепира негативне догађаје. У почетку рада смо описали лингвистичке манифестације, те склоности ка негативним догађајима и разлоге због чега је значајно да се обрати пажња на негативни језик. Негативни језик прожима и боји нашу перцепцију онога што је речено у вези са њим. Затим, користећи анализу помоћу корпуса, класификовали смо средства која играју улогу у изражавању негативне евалуације у оквиру лексикограматике и дискурсивне семантике. Ова уопштена класификаија се уклапа у различите нивое изражавања у оквиру системске функционалне лингвистике. У свом будућем раду требало би одабрати одређени корпус и квантитативно и квалитативно описати специфичне феномене и обрасце који изражавају негативност. Будући рад би требало да обухвата детаљну анализу феномена у нашој таксономји, прво ручним путем који би обавили анотатори. Након детаљног описа феномена требало би 
развити аутоматску анализу која би се заснивала на сличном методу као у сентимент анализи.

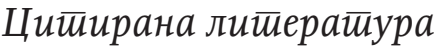

Вольф, Е. М. Функциональная семантика оценки. Москва: Книжный дом „Либроком”, 2009.

Молотков, А.И. Фразеологический словарь русского языка, Москва: Русский язык, 1986.

Трнавац, Радослава. Кохерентност и евалуација у тексту у српском и руском језику. Београд: САНУ, 2017.

Biber, D., \& Finegan, E. Styles of stance in English: Lexical and grammatical marking of evidentiality and affect. Text 9 (1), 1989: 93-124.

Boucher, Jerry D., \& Osgood, Charles E. The Pollyanna hypothesis. Journal of Verbal Learning and Verbal Behaviour, 8, 1-8, 1969.

Burke, Kenneth. (1966). Definition of man. In Kenneth Burke (Ed.), Language as symbolic action: Essays on life, literature, and method (pp. 3-24). Berkely: University of California Press.

Cambria E, Havasi C., \& A. Hussain. SenticNet 2: A semantic and affective resource for opinion mining and sentiment analysis In: Youngblood GM, McCarthy PM (ed.) Proceedings of the 25th International Florida Artificial Intelligence Research Society Conference, FLAIRS-12, Palo Alto, CA, USA: Association for the Advancement of Artificial. Twenty-Fifth International Florida Artificial Intelligence Research Society Conference, FLAIRS 12, 23.5.2012 - 25.5.2012, Marco Island, FL, USA, 2012, pp. 202-207.

Clough, P. T., \& J. O'Malley Halley (eds.). The affective turn: Theorizing the social. Durham. NC: Duke UP, 2007.

Curtis, Valerie. Don't Look, Don't Touch, Don't Eat. Chicago: University of Chicago Press, 2013.

Dodds, Peter Sheridan, Clark, Eric M., Desu, Suma, Frank, Morgan R., Reagan, Andrew J., Williams, Jake Ryland, ... Danforth, Christopher M. Human language reveals a positivity bias. Proceedings of the National Academy of Sciences, 112(8), 2015: 2389-2394.

Garcia, D., Garas, A., \& Schweitzer, F. Positive words carry less information than negative words. EPJ Data Science 1(3), 2012.

Goddard, C., Taboada, M., \& Trnavac, R. Semantic Descriptions of 24 Evaluational Adjectives, for Application in Sentiment Analysis. Simon Fraser University, 2016a.

Goldberg, A. E. Constructions at Work: The Nature of Generalization in Language. Oxford: Oxford University Press, 2006.

Horn, L. A Natural History of Negation. University of Chicago Press, 1989.

Hunston, S. Corpus Approaches to Evaluation: Phraseology and Evaluative Language. Routledge, New York, 2011. 
Hunston, S., \& G. Thompson. Evaluation in text: Authorial stance and the construction of discourse. Oxford: Oxford University Press, 2000.

Israel, Michael. The pragmatics of polarity. In Laurence Horn \& Gregory Ward (Eds.), The Handbook of Pragmatics (pp. 701-723). Malden, MA: Blackwell, 2004.

Jing-Schmidt, Z. Negativity bias in language: A cognitive-affective model of emotive intensifiers. Cognitive Linguistics 18(3), 2007: 417-443.

Kahneman, Daniel, \& Tversky, Amos. Prospect Theory: An analysis of decision under risk. Econometrica 47(2), 1979: 263-291.

Keith, William M., \& Lundberg, Christian O. The Essential Guide to Rhetoric. Boston, MA: Bedford/St. Martin's, 2008.

Liu, F.,W. Dong, L. Bin, \& L. Yang. Improving blog polarity classification via topic analysis and adaptive methods. In Proceedings of Human Language Technologies: The Annual Conference of the North American Chapter of the ACL, pages 309-312, Los Angeles, CA, 2010.

Liu, Bing. Sentiment Analysis and Opinion Mining. Morgan \& Claypool, 2012.

Mann, W. C., \& Thompson, S. A. Rhetorical Structure Theory: Toward a functional theory of text organization. Text 8(3), 1988: 243-281.

Martin, James R. English Text: System and Structure. Amsterdam and Philadelphia: John Benjamins, 1992.

Martin, James R. Evolving systemic functional linguistics: Beyond the clause. Functional Linguistics, 1(3), 2014: 1-24.

Martin, J. R., \& P. R. R. White. The Language of Evaluation: Appraisal in English. London: Palgrave/Macmillan, 2005.

Ortony, A., G. L. Clore \& A. Collins. The cognitive structure of emotions. New York: Cambridge University Press, 1988.

Pang, B., \& L. Lee. Opinion mining and sentiment analysis. Foundations and Trends in Information Retrieval, 2(1-2), 2008: 1-135.

Picard, Rosemary W. Affective computing. Cambridge, MA: MIT Press, 1997.

Ribeiro, F. N., Araújo, M., Gonçalves, P., Gonçalves, M. A., \& Benevenuto, F. SentiBench: A benchmark comparison of state-of-the-practice sentiment analysis methods. EPJ Data Science, 5(23), 2016.

Rick, S., G. Loewenstein. The role of emotion in economic behavior. In Lewis, M., Haviland-Jones, J. M., \& Barrett, L. F. (Eds.). Handbook of Emotions, 3rd Edition. New York: Guilford, 2008.

Rozin, P., Berman, L., \& Royzman, E. B. (). Biases in use of positive and negative words across twenty natural languages. Cognition and Emotion 24 (3), 2010: $536-548$.

Rozin, P., \& Royzman, E. B. Negativity bias, negativity dominance, and contagion. Personality and Social Psychology Review 5(4), 2001: 296-320.

Scherer, K. R. The component process model: a blueprint for a comprehensive computational model of emotion, in: Blueprint for Affective Computing: A Sourcebook, (eds.) Scherer K. R., T. Bänziger, \& E. B. Roesch (Oxford: Oxford University Press), 2010, 47-70. 
Taboada, M., \& Trnavac, R. (Eds.). Nonveridicality and evaluation: Theoretical, computational and corpus approaches. Leiden: Brill, 2013.

Thompson, G., \& L. Alba-Juez, (eds.) Evaluation in Context. John Benjamins, 2014.

Voas, E. M. \& A. Park. Introduction for special section: Attitudes: Ontology, methodology, impact. Sociological Research Online 19 (1), 2014.

\title{
Радослава Трнавац
}

\section{СИСТЕМА ВЫРАЖАНИЯ НЕГАТИВНЙ ОЦЕНКИ В РУССКОМ ЯЗЫКЕ}

\begin{abstract}
Резюме
Данная работа описывает предварительную классификацию лингвистических средств, которые употребляются для выражения негативной оценки в русском языке. Представленная классификация базируется на методе корпусного анализа.

Ключевые слова: негативная оценка, классификация, системно-функциональная лингвистика, лексикограмматика, семантика дискурса
\end{abstract}

